\title{
Postmodern Müzedeki Dönüşümler
}

Transformations in the Postmodern Museum

\author{
Jane K. NIELSEN* \\ *PhD Candidate in Museum and Gallery Studies, University of St. Andrews \\ Türkçeye çeviren: \\ Fethiye ERBAY** \\ **Prof. Dr., İstanbul Üniversitesi, Sosyal Bilimler Fakültesi Müze Yönetimi Bilim Dalı Bölüm Başkanı \\ E-posta: erbayf@istanbul.edu.tr \\ ORCID: 0000-0002-6988-5367 \\ Özgül ÇETiN*** \\ ***Doktora Öğrencisi, İstanbul Üniversitesi, Sosyal Bilimler Fakültesi Müze Yönetimi Bilim Dalı \\ E-posta: cetinozgul@yahoo.com \\ ORCID: 0000-0001-7007-1267
}

\section{Anahtar sözcükler:}

Modernizm, Postmodernizm, Dönüşüm, Fütüroloji.
ÖZ

Bu makalede postmodern müze kavramı, epistemolojik tanımlar ve gelecek bilim teorileri üzerinden tartıșımaktadır. Postmodern müzeler de ziyaretçi odaklı etkileşim ve katıım ön plana çıkmaktadır. Bunun yanı sıra, müzelerin artan yeni sorumlulukları karşısında özellikle küratörün rolü de önemli ölçüde değişmektedir. Bu durumun müzelerin ișleyiși, yorumlama ve iletișim kurma șekli üzerinde rolü büyütür. Bu makale, postmodern müzenin bazı teorik perspektiflerine ve küratörlerin günlük faaliyetlerinde daha geniş sorumlulukları nasıl ele aldıklarına bakarak, bu değişikliklerin hem müze pratiğini hem de teorisini nasıl etkilediğini belirlemeyi amaçlamaktadır. Dönüşüm ve fütüroloji, müzelerin sürekli olarak bilgiyi dönüştürme ve geleceğin müzeleri olma ihtiyaçları etrafında dönen dönüștürücü güçtür. Bu bağlamda Dönüștürücü Müze kavramı, bize yeni bir müze modeli sunarak aynı zamanda müzelerin karşılaştıkları zorlukları da özetlemektedir.

\section{Giriş}

Postmodern müze kavramı müzecilik literatüründe ve araştırmalarda uzun süredir kullanılmaktadır. Müze uzmanlarının nasıl çalıştıklarını, amaçları ve ziyaretçi iletişimi hakkında nasıl düşündüklerini belirlemek açısından postmodern müze önemli bir kavramdır (Hooper-Greenhill 2000). Bu makale müzelerin yönlerini aşağıdaki sorular aracılığıyla tanımlamayı amaçlamaktadır: Postmodern müze kavramı günümüz müzeleri için halen geçerli mi? Postmodern müze fikri, müzelerin bugün karşı karşıya kaldığı baskılara, amaçlara ve hedeflere fayda sağliyor mu? Hem müze çalışanlarının gelişimi hem de ziyaretçi etkileşimi için daha uygun bir deneyim yaratmak amacıyla müzelerin yararlanabileceği başka disiplinler veya uygulamalar var $\mathrm{m}$ ?

Birçok müze, koruma, araştırma, etkileşim ve ziyaretçi katılımının getirdiği sorumlulukları şu anki finansal sıkıntı ortamında yönetmekte zorlanmaktadır. Bu sebeple müze uzmanları, ziyaretçi katılımına öncelik vermenin ne derece doğru olduğu yönünde tartışmalarını sürdürmektedirler. Dolayısı ile gelişmeler de yeni yaklaşımlar benimsemek ugyun olacaktır. Felsefe, sosyoloji ve fütüroloji gibi akademik disiplinler ve hikâye anlatımı, müze personelinin eğitimi ile ilgili uygulamalarda ve müzelerin karşılaştı̆̆1 zorlukların çözümünde yardımcı olabilir. Günümüzde müzelerin çoğu günlük uygulamalarında zaten 
bu disiplinlerin unsurlarını kullanmaktadırlar. Bununla birlikte, bu uygulamalar aynı zamanda daha önce postmodern müzede ele alınmayan esneklik, yaratıcılık, katılım ve dönüşüm gibi kavramlara özen gösterilmesini gerektirmekte ve tamamen yeni bir müze fikrini de şekillendirmektedir. Diğer bir deyişle, tecrübeyi, bilgiyi ve etkinlikleri her türlü iletişim ve yoruma dönüştürmeye hazır bir müze fikrinden bahsedilmektedir.

Bu makale, postmodern müzenin bazı zorluklarını ve dönüşümlerini tartışmakta ve fütürolog Richard Slaughter'ın 'The Transformative Cycle' (Slaughter 2004) teorisine dayanan yeni bir dönüştürücü müze modeli önermektedir. Slaughter'in teorisi, her yeni kavram veya fikrin geçmesi gereken farklı inovasyon aşamaları$\mathrm{n} 1$ tanımlar. $\mathrm{Bu}$, teoriyi müzeolojinin dönüşümü açısından özellikle ilginç kılmaktadır ve dönüşümleri doğrudan fütüroloji bilimiyle ilişkilendirmektedir. Fütüroloji, alternatif gelecekler hakkında sistematik ve açık düşünmeyi içeren nispeten yeni bir akademik disiplindir. Fütürolojinin kesin kökeni bilinmemekle birlikte, olasılıklar ve tahminler her zaman akademik disiplinlerin ve araştırmanın bir parçası olmuştur (Bell 2009). Fütüroloji, öngörüye dayalı yeni bir eğilim olarak da görülebilir. Fütüroloji ne geleceği tahmin etmekle ne de gelecekteki gerçeklerle ilgilidir. Geleceği aydınlatmakla ilgili olup, insanların bunun hakkında düşünmesini ve böylece şimdiki zamana yardımcı olmasını sağlar. Bu teorileri ve bakış açılarını güncel müze gelişimi ve müzeoloji tartışmalarına uyarlayarak, dönüşüm ve esneklik konularını doğrudan ele alan Dönüştürücü Müze gibi yeni bir müze modeli geliştirmek mümkündür.

\section{Somut Olmayanı Tanımlama}

Eilean Hooper-Greenhill (2000: 152-153) Müzeler ve Görsel Kültürün Yorumlanması' adlı eserinde ilk defa post-müzeden bahseder ve postmodern ilkelere dayanan yeni bir müze kavramını tanımlar. Müze felsefesinin bu yeni aşamasını şu şekilde tanımlamıştır: "Müzelerin koleksiyon toplama safhasi sona erdi. Post-müzeler, yine eserleri toplayıp, bakımın yapacak, ancak onların kullanımına odaklanacaktır. Buna ek olarak, post-müzeler, somut olmayan mirasla da eşit derecede ilgilenecektir". Somut olmayan miras kavramı, müzeler için başa çıkması zor bir konu olmakla birlikte, çoğu müze somut olmayan mirası ziyaretçi iletişiminin, katılımının bir parçası olarak görmektedir. Bu kavram tam olarak ilkesel ya da stratejik olarak tanımlanamadı ̆̆ı, açıklanamadığı halde, çok az sayıda müze tarafından soyutun neleri kapsayabileceği üzerine düşünülmüştür. Bu kavram, resmi müze tanımlarına da girmiş bulunmaktadır. ICOM'un 2001 ve 2007 yılına ait iki tanımı çok benzer görünseler de bunlar arasında somut olmayan (soyut) miras açısından birkaç önemli değişiklik vardir:

\section{Uluslararası Müzeler Konseyi'nin tanımı, 2001:}

Müze, kâr amacı gütmeyen, topluma ve toplumun eğitimine hizmet eden, kalıcı ve kamuya açık, insana ve yaşadığ 1 çevreye dair tanıklık eden somut kanıtları çalıșma, eğitim ve eğlenme amaçli, koruyan, araştıran, ileten ve sergileyen bir kurumdur (1).

\section{Uluslararası Müzeler Konseyi'nin tanımı, 2007:}

Müze, kâr amacı gütmeyen, topluma ve toplumun eğitimine hizmet eden, kalıcı ve kamuya açık, insana ve yaşadığı çevreye dair tanıklık eden somut ve somut olmayan mirası eğitim, çalışma ve eğlenme amacıyla koruyan, araştıran, ileten ve sergileyen bir kurumdur (1).

2001 tanımında "somut kanıtlar" ve 2007'de ise "somut ve somut olmayan miras" üzerinde durulmaktadır. Genel olarak müze tanımlarında sadece işlevsellik ve kurumun amacıyla ilgili olarak değişimler yanında, ICOM böylelikle "somut olmayan mirası" da temel işlevler arasında tanımlamıştır. "Somut olmayan", aynı zamanda postmodern müzeyi tam olarak tanımlayan bir kavram olarak koleksiyon ve nesne odaklı müzelerin artık daha çok ziyaretçinin öğrenmesine, etkinliklerine ve etkileşime odaklanmasına vurgu yapar. Bu nedenle kavram, postmodern gelişmelerin ve yaklaşımların bir parçası olarak tanımlara girmiş durumdadır. Bu makale, bu gelişmelerin özellikle küratörlerin rolüne olan etkisine ve önemine değinmektedir. 


\section{Postmodern Müze Küratörü}

Günümüzde birçok müze, varoluş amaçlarını değil potansiyel ziyaretçilerine, kendilerine dahi anlatmakta güçlük çekmektedirler. Belirli bir amacın olmaması, müzeler için kötü bir geleceğe işaret etmektedir (Black 2012: 4).

Müzelerde ziyaretçi iletişimine ve etkileşimine öncelik vermenin koleksiyon yönetimi ve korumayı tehlikeye atıp atmayacağ 1 uzun süredir tartışılmaktadır (Black 2012; Heal 2012). Aslında bazen iletişim ve öğrenmeyi tartışmanın, koleksiyonlara veya nesnelere olan vurguyu azaltmaya yönelik bir girişim olduğunu söylenebilir. Black'in de belirttiği gibi, ziyaretçi etkileşimi konusu müzeleri bir anlamda parçaladı ve birçoğunun da amacını ve ilgisini tanımlayamamasina neden oldu. Bu tartışmalarda disiplinler arası bağlantıya nadiren odaklanılmaktadır: "İlginç ve ilgi çekici metinler yazmak, yorumlamak, açıklamak ve bă̆ kurmak ve çevremizdeki dünyayı anlamak için koleksiyonları anlamamız gerekir" (Heal 2012: 4). Museum Journal Editörü, Sharon Heal ayrıca müzelerin anlaması gereken birçok şeye vurgu yapmaktadır: "Halkın kim olduğunu, neden müzeye geldiklerini ya da neden gelmediklerini anlamamız gerekiyor. İlgi alanların ve öğrenme tarzlarını, hikâyelerini ve koleksiyonlarla kurdukları bağları bilmemiz gerekir. Bunlar ve koleksiyon hakkındaki bilgiler arasında bir çelişki olmamalıdır" (Heal 2012: 4). Heal'ın da belirttiği gibi, koleksiyonlara ve ziyaretçilere yönelik bu tartışmalar garip görünebilir. Çünkü bu konuda fikir ayrılığının olmaması gerekir. Aslında bu aynı zamanda, çoğu müze uzmanının kendi uzmanlık alanlarına giren konularda ne kadar hevesli olduğunun da bir göstergesidir. Kişinin sadece kendi uzmanlığını korumaya çalışması yerine, bu coşkuyu müze için daha faydalı bir şeye dönüştürmek için kullanması ilginç olabilir. Çoğu küratör, ziyaretçi iletişimi ve ziyaretçiyle direk etkileşime girecekleri alanlar için zaten kendi uzmanlık alanlarını genişletmektedir, bu uzun zamandır küçük müzelerde uygulanmaktadır. Bununla birlikte, farklı müzelerden bir grup küratörle röportaj yapan John Holt, Museums Journal'ın Mart 2013 sayısinda, kesintiler ve maliyet tasarruflarından dolayı küratörlerin işlerinin tehlikede olduğunu düşün- düklerini, geçici olarak alınan uzmanların daha fazla tercih edildiğini belirtmektedir (Holt 2013: 30). İster finansal kesintiler ister daha fazla ziyaretçi ve iletişim odaklı yeni nesil küratörlerin ve araştırmacıların eğitimi nedeniyle olsun, bu küratöryel rolün de bir dönüşüm içinde olduğu kabul görmektedir. Küratörlerin değişen rolü, şüphesiz müzelerin gelecekteki amaç, hedef ve stratejilerini belirlemede etkili olacaktır. Bu durum, bu dönüşümlerin bilincinde ve müze araştırması ve iletişiminin doğal gelişim sürecinde yer almaları için müzelere alan sağlayan yeni bir model gerektirmektedir. Bazı müzelerin, toplulukları dâhil etmenin yeni yollarını geliştirerek, ziyaretçi katılımını genişleterek veya araştırmayı dönüştürerek aynı anda farklı kullanıcılarla etkileşime girebilmek için çaba harcamalarını gerektirecektir. Bu, finansal açıdan sıkıntı dönemlerinde ve birçok müzenin personel azalttığı dönemde doğal olarak göz korkutucu görünebilir. Bununla birlikte, beklentiler, küratöryel çalışmanın bazı ilginç yeni yönlerini de ortaya çıkarmaktadır:

- Reading Müzesi küratörü Brendan Carr: “Bazı insanlar küratörlerin her türlü bilginin kaynağı olduğunu düşünüyorlar; sorun değil, ama sadece bir Google olmamalısınız, bunun yerine insanları keşfetmeleri için yönlendirmeniz gerektiğini düşünüyorum" (Holt 2013: 30).

- Michelle Brown, Londra Ulaşım Müzesi küratörü: "Bir gün posterlerle ilgili görev alabilirim, diğer bir gün sanatçılarla çalışıyor olabilirim" (Holt 2013: 33).

- Mark Macleod, operasyon ve proje küratörü, Museum of the University of St Andrews: "Küratörler niteliklerini sergilemeden kendilerini 'uzman' olarak görmemelidirler. İzleyiciye bir obje hakkında birden fazla teori sunarak çok daha geniş bir içerik sağlayacak bir Wikipedia modelinin müze sektöründe yer alması muhtemeldir" (Holt 2013: 32).

Müze işlevleri hem ziyaretçiler hem de uzmanlar bağlamında, küratörün görevlerinin değişmesi fikriyle birlikte bir dönüşüm içindedir. Ziyaretçilerin beklentileri, küratörün görevinin kapsamını uzman, iletişimci, öğretmen ve motive eden kişi olarak genişletmektedir. Daha da önemlisi, küra- 
törlerin bu rolleri tam olarak yerine getirmesi gerekmektedir (Holt 2013: 32). Bu, postmodern müze kavramını da değiştirmekte, müzeler dikkatini, ziyaretçilerin beklentileri karşısında uzmanların bu beklentileri, bilgilerini kullanarak nasıl ileteceklerine yöneltmiş durumdadır. Yukarıdaki alıntılardan ikisinin Google ve Wikipedia'dan bahsetmesi de ilginçtir. Ziyaretçilerin ilgileri, çevrimiçi medya ve müzelerin bunların aracılığıyla ziyaretçilerle nasıl iletişim kurduğumuza bağlı olarak şekillenmektedir.

Değişim tüm organizasyonların ayakta kalabilmesi için gereklidir. Ancak bugün müzelerin yapmaya çalıştığı şey tam olarak nedir? Ziyaretçilere ne tür bir etkileşim, yorum ve bilgi sunmak istiyorlar? Bazı müzeler, geleceği düşünerek şimdiden ziyaretçiye yönelik uygulamaları deneyimlemeye başladılar.

\section{Geçmişi ve Bugünü Gelecek İçin Dönüştürmek}

Gelecek geçmişin tekrarı olmayacağı için, Fütüroloji (gelecek bilimi) hem bireyler hem de kuruluşlar için anlam kazanmaktadır. Fütüroloji insanların veya kuruluşların gelecek hakkında endișe etmeleri yerine kendilerine güvenmeleri için uygun araçları yaratabilir. Fütüroloji gelecekteki olasılık analizlerini içerir. Geleceği kullanarak bugünü değiştirmek, dolayısıyla yenilik yaratmak için olasılıkları keşfederek tarih, kültür, hedefler ve görüşlerdeki farklllıklar hakkında erken dönemde bilgi edinir. Bu disiplinin, kurumlara stratejik planlama ve amaç tanımları yaparken önemli ölçüde yardımı olabilir. Fütüroloji, gelecek için alternatif olasılıkları anlamak ve bunları aktif olarak değerlendirmekle ilgilidir. $\mathrm{Bu}$ nedenle gelecek bilim, alternatif görüşlere, söylemlere ve zorluklara açı disiplinler arası bir alan olarak görülmelidir (Bell 2009). Genellikle Fütüristler, tarih, sosyoloji ve eğitim gibi çeşitli akademik alanlara farklı açılardan yaklaşırlar.

Fütüroloji, çok çeşitli sistematik, katılımcı, stratejik ve yorumlayıcı analiz yöntemleri sunmaktadır. Bazıları örgütsel analiz için, bazıları sosyal, kişisel veya metodolojik yaklaşımlar için geçerlidir. Bu makale, müzelerin hedefleri, amaçları ve gelecek stratejilerini tanımlama olanaklarını artırabilecek belirli bir teoriye, Dönüşüm Döngüsünü
(Transformative Cycle) daha yakından inceleyecektir.

Dönüşüm Döngüsü (T döngüsü), yeni fikirlerin, kavramların veya yeniliklerin farklı aşamalarını tanımlayarak değişimlerin uygulanması süreçlerine bakar. 1980'lerin başında Fütürist Richard Slaughter tarafından geliştirilmiştir. Swinburne Teknoloji Üniversitesi'ndeki Avustralya Öngörü Enstitüsü'nde Luke Naismith ve Neil Houghton tarafından da incelenmiștir (Slaughter 2004; Naismith 2004: Houghton 2004). Slaughter'ın değindiği önemli noktalardan bir tanesi, çoğu zaman geçerli bir nedene bağlı olarak, sosyal sistemlerin her zaman değişime direnmesidir.

Michel Foucault'un belirtiği gibi (1972: 89-141); bir sistem genellikle değişimleri ancak rahatsız edici bir durum ile karşılaştı̆̆ında kabul eder.

Bu rahatsızlık durumu, Dönüşüm Döngüsü'nün (The Transformative Cycle) dört aşamasında karşımıza çıkabilmektedir (Slaughter 2004: 6):

- Anlam kırılmaları

- Yeniden Kavramsallaştırmalar

- Çatışma ve Müzakere

- Resmileştirme

T-döngüsünün tanımlamaya çalıştığ 1 şey, her yenilikçi kavramın aşması gereken bu dört durumdur:

Bir sorun belirlendiğinde genellikle bu durum anlam kırılmalarını da beraberinde getirir; “... bir zamanlar sosyal etkileşime katkı sağlayan anlayışlar, kavramlar, değerler ve anlaşmaların şu ya da bu nedenden dolayı artık bir sorun haline gelmesine atıfta bulunur" (Slaughter 2004: 6). Elbette birçok kırılma sorun olarak görülebileceğinden aynı zamanda işlevsizdir de. Bununla birlikte, bir zamanlar veri olarak kabul edilen, karmaşık fikir, anlayış ve anlam oluşumları artık öyle görülmeyebilir. Bu tanım, özellikle Foucault'un bir kültürün değerlerini, kodlarını, dillerini ve anlamlarını tanımlayan bilgi (episteme) tanımlarına yakındır - bu anlayışa geçiş, bir çöküş meydana geldiğinde gerçekleşir. Belirli fikirlerin çöküşünün yanı sıra, müzeler uzun bir süredir iletişim yöntemlerinin genel yönleriyle, koleksiyonları sergilemede ve yorumlamada ye- 
ni yollarla mücadele etmiştir. Sosyal olarak dâhil olma, topluluk katılımı ve artan ziyaretçi sayısı gibi gereksinimler, finansal açıdan zor bir döneme denk gelmiştir. Bu, müzelerin yalnızca ziyaretçi iletişimi ve sergi etkileşimine yönelik stratejik yaklaşımlarını değiştirmelerine sebep olmuyor; ayrıca değişen gereksinimlerle başa çımanın yeni yollarını bulmaları da gerekiyordu. Bazı müzeler bu gereksinimleri, belirli ziyaretçi gruplarına yönelik projeler oluşturarak veya Kelvingrove Sanat Galerisi ve Müzesi (Morgan 2013; Sharp 2012) gibi esneklik içeren yeni sergi yaklaşımları girişiminde bulunarak karşılamışlardır.

Bir çöküş meydana geldiğinde, değişim için medya aracılığıyla birçok fikir ve öneri ortaya atılacaktır. Bu fikirler genellikle gelecek hakkında endişe ettikleri için değil, ancak sorun olarak görülebilecek şeylere karşı, geleceğe yönelik çözümler sunmak için ortaya atılırlar. Pek çok müze, QR kodlarının, çevrimiçi oyunların ve etkileşimli sergi sunumları gibi yeni teknolojilerin kullanımı sayesinde yeni iletişim yaklaşımları geliştirme fırsatını yakalamıştır. Müzeler genellikle web sitelerine, sergilerine veya sosyal medyada kendilerine duyulan ilgiye önem verdiklerinden, kendi rol ve amaçlarına daha fazla odaklanmaktadırlar. Bu konular hakkında artık daha fazla tartışılmaktadır ve müzeler de artık çekinmeden bu tartışmalara dâhil olmaktadır.

Yeni fikirler kaçınılmaz olarak çatışmaları ve müzakereleri de beraberinde gerektirecektir. Bazı çatışmalar, asla müzakere aşamasına gelmeyecektir, çünkü müzakere için iki tarafın birbirlerinin fikirlerini dinlemeye veya eşit olarak görmeye istekli olmaları gerekir. Bu sebeple çatışmadan müzakereye varmanın yolu çok uzun ve karmaş1k olabilmektedir. Müzakere seviyesine erişebilmek, 1srar ve destek gerektirecektir. Bazen bir fikirden vazgeçilmesi ya da fikrin değiştirilmesi gerekebilir. Yeni yaklaşımları deneyimlemek hem başarısızlığa hem de başarıya götürecektir. Bazı müzeler, ziyaretçi katılımı, koleksiyonların sunumu ve uzmanlık alanlarını ön plana çkararak yeni ve başarılı yollar deneyimlediler. Diğerleri belki etkileşimi daha az deneyimlemiş olabilir, belki de iletişime odaklanarak koleksiyonlarından ödün verdiklerini de hissedebilirler.
Bu çatışmalardan ve müzakerelerden, bazıları bireysel müzeler, bazıları ise daha kapsamlı müzeler için tartışılan, birçok farklı strateji ve yaklaşım ortaya çıkmaktadır.

Seçim, temelde yeni fikirlerin veya kavramların uygulanmasiyla ilgilidir. Her seferinde hayata geçirilebilecekten çok daha fazla fikir ve öneri üretilmektedir. Bununla birlikte, seçim kriterlerinin sosyal sistemlerde adil ya da yeterli olduğu tartışmalıdır. Bu nedenle, her zaman en iyi fikirlerin veya önerilerin alındığı söylenemez (en iyinin tanımı da doğal olarak bakış açısına bağlı bir meseledir). Dolayısıyla model, bu dönüşüm sürecinin gelişmeler ile tam olarak örtüştüğünü ileri sürememektedir. Bazen bu tür uygulamalar olumsuz sonuçlar da doğurabilir. Seçim ve onaylama süreçleri, büyük ölçüde yeni önerileri kimin kabul ettiğine ve önerilerin nasıl uygulanacağına bağlıdır. Süreç, genellikle belirli ilgi alanlarına hizmet edecek ve çoğunluk için işe yarayan anlamları geçerli kılacaktır (Slaughter 2004: 6-8). Müzeler, bunu genellikle uzmanlar ve araştırmacılar arasındaki genel tartı̧̧malarda yaşar. Ancak öneriler, fikirler ve yaklaşımlar tıpkı müzeler gibi çeşitlilik göstermektedir. Bir müze, kendi amacına odaklanmalı ve araştırma ve iletişim yaklaşımlarını amacına uygun olarak tanımlamalıdır. Slaughter, kabul görmüş anlamların genellikle aynı çöküşs sürecine uğramayacağına, zaman içinde orijinal bağlamın değiştiğine ve böylece diğer kavramlara yeni bir anlam katabileceğini savunmaktadır. Eğer yeni bir fikir geniş çapta bir destek alacak kadar güçlüyse, yeni koşulları da beraberinde getirecektir. Bazen yeniden kavramsallaştırma süreci, bu süreci engelleyici, karşı tepkilerin oluşmasına da sebep olabilir. Ayrıca, çatışmalar yaşanabilir ve bu aynı şekilde odağı da değiştirebilir (Slaughter 2004: 9-10).

T döngüsünün özellikle üç bağlamda yararlı olduğu kanıtlanmıştır (Slaughter 2004: 11-12):

- Genel amaçlı bir çalıştay ve öğretim aracı olarak

- Belirli kurumlarda değişimin analizi için bir araç olarak

- Araştırma ve kültürel eleştiri aracı olarak

İlginç bir şekilde, T-döngüsünün kendisi, yeni anlamların geliştirilmesine yol açabilecek bir ka- 
rışıklık veya "bozulma" ortaya çıkarabilir: "Bu nedenle, T-Döngüsünün kendisi, anlamın geri kazanılmasıyla ilgilenen, geleceğe yönelik bir yaklaşımın parçası olarak düşünülebilir" (Slaughter 2004: 12).

Yeni anlamların uygulama süreçleri biraz zaman alabilir. Bu nedenle fikirler T-döngüsünde çok uzun bir süre ileri geri giderek farklı aşamalardan geçerler. Bununla birlikte, neredeyse tüm kültürel yenilikler sosyal yeniliklerin bir sonucu olarak ortaya çıkar. Dolayısıyla bu süreçler sosyal öğrenmeyi de içerir. Sosyal öğrenme, genellikle bir çözüme ulaşmak için sadece nelerin işe yaradığının analizlerini değil, nelerin işe yaramadığının analizlerini içerir.

Dönüşüm, özellikle fütüroloji (gelecek biliminin) ve ilgili disiplinlerin önemli bir unsuru olarak görülmelidir: “Dönüşüm, bireyler, kurumlar ve toplumlar için bütünsel ve derin bir dönüşümü içerir. Hem insanların tutum ve inanç sistemlerindeki içsel değişimini hem de bu değişimlerin bireysel ve kolektif düzeyde davranışlara nasıl yansıdığını kapsar" (Naismith 2004: 21). Dönüşümün her şeyden önce kişisel dönüşümle ilgili olduğu, çünkü genellikle diş faktörleri değiştirmeden önce içsel bakış açısında bir değişimin olması gerektiği söylenebilir. Bununla birlikte, dönüşüm farklı seviyelerde gerçekleşebilir. Farklı zamanlarda da ortaya çıkabilir ve dönüşüm döneminden önce ve sonra devam eden dinamik süreçleri de içermektedir.

T döngüsü fikri, müzeler için amaçların ve stratejilerin planlanmasında yeni bir yaklaşım getirebilir.

\section{Dönüştürücü Müze}

Dönüştürücü Müze (2) terimi, hiç şüphesiz müzelerin, restorasyonlar, misyon bildirimleri veya öğrenme ve sergileme uygulamaları gibi alanlardaki dönüşüm sürecinde farklı bağlamlarda tekrar ortaya çıkacak bir terimdir. Bu terim, müzecilikte dönüşümün gerekliliğine odaklanmak ve aynı zamanda yenilikçi bir gelişim süreci açısından T döngüsünün bu kavramlarla da ilgili olduğu için seçilmiştir. Burada, müze dönüşümleri hakkında yeni bir metodolojik düşünme biçimi oluşturmak amaciyla, bunu postmodern müzeye bir gelişimin parçası olarak T-döngüsü ile beraber dâhil etmeye çalışılacaktır.

Gelecek düşüncesi müzeler için yeni değildir. Bununla birlikte, çoğu müze için değişim kavramını ilişkilendirmek zor olabilir: "Toplum, bizden çok daha hızl değişiyor. Müze değerleri ve uygulamaları açısından hızlıca bir değişime gidilmesi gerektiğini kabul etmeliyiz. Tüm finansal zorluklara rağmen, yirmi birinci yüzyılın taleplerini karşılamalıyız. Değişime dirençli olan bir meslek grubu için tabii ki bu çok zorlayıcı bir süreç olacak. Zorunlu değgişiminin gerçekleşebilmesi için hepimiz artık birer fütürist olmalıyı" (Black 2012: 8).

Yeni bir düşünce tarzı artık açıkça müzelerde yer almaktadır. Bilgi kaynağı ve Ziyaretçi beklentileri değiştikçe, sergiler esneklik uygulanacak şekilde tasarlanmaya başlandi. Yeni bilgiler eklemek ya da yeni objeler dâhil etmenin yanı sıra ayrıca ziyaretçi katılımını da sağlamak için girişimlerde bulunulmaktadır. Bunun bir örneği, yeni restore edilmiş olan ve büyük bir tadilattan sonra 2006 'da yeniden açılan Kelvingrove Sanat Galerisi ve Müzesi'dir (Morgan 2013; Sharp 2012). Kelvingrove Sanat Galerisi ve Müzesi (2012), değişen toplum ilgisine göre vitrinleri geliştirmeyi ve değiştirmeyi mümkün kılacak ve aynı zamanda gelecekteki sergiler için finansal yatırım ihtiyacı$\mathrm{n}$ azaltacak daha esnek bir sergileme sistemi uygulamaya çalıştı (3). Müze bu konuda bazı olumsuz geri bildirimler almıştır (Sharp 2012: 26). Gelecek sergi tasarımları hakkında bu şekilde düşünmek yeni bir yaklaşımdır. Ayrıca müzelerin ziyaretçilerin değişen ilgilerine cevap vermeye başladığını ve hatta bunu sergi iletişiminde de uyguladıklarını göstermektedirler. Teknoloji kullanımındaki değişim, doğrudan ziyaretçi katıl1mı gereksinimleri ve değişen vitrin tasarımlarına duyulan ihtiyaç, müzeleri geleceği düşünmeye, esneklik ve dönüşüme doğru yönlendirdiği görülmektedir.

Müze uygulamalarında ve teorisinde değişim ve dönüşüm arasında bir fark olduğu da söylenebilir. Gelişim için her şeyi değiştirmek her zaman gerekli olmayabilir. Bununla birlikte, dönüşüm daha küçük veya daha karmaşık değişikliklerin yanı sıra daha büyük ve daha genel değişikliklerle ilgili de olabilir. İletişim ve öğrenme hızla 
gelişmektedir. Dolayısı ile müzeler, geçmişi ve bugünü aynı anda her seviyeden her nesil için anlamlı ve yararlı kılmak zorundadır. Bu imkânı sağlamaları gerekmektedir, dolayısı ile dönüşüm ve esneklik müzeler için temel unsur olmuştur. Bu şekilde, bir obje bir gün bir çevrimiçi oyun veya bir öğrenme programı aracılığıyla çocuklarla veya gençlerle iletişime geçebilir - ertesi gün yaşlılar için düzenlenen anılarını anlattıkları kurslarda ise yaşlılarla etkileşim kurabilir vb.

Dönüşümün gelişimi, modernizmin ve postmodernizmin epistemolojik tanımlarıyla da tanımlanabilir; burada modernizm anlam yaratmak ve mantığı kullanma hakkındayken, postmodernizm ilgi yaratmak ya da bu anlamı ve mantığ ile ilgilidir. Dönüşüm, postmodernizmin tanımladığı ilgili anlam ve mantığı dönüştürmekle ilgilidir. Dönüştürücü bir müze, postmodern duyguyu ve mantığı geleceğe dönüştüren ve esneklik, tartışma ve katılım yoluyla bir dönüşümün anlamlı olmasını sağlayan bir müze olacaktır. Dönüştürücü müze bu nedenle yeni bir anlayış biçimi olarak görülebilir. Araştırmalar da bilgi ve bilgilendirme, öğrenme ve sergileme yaklaşımları ve epistemolojik anlayışlar açısından ve hikâye anlatımı, sosyal medya ve müzecilik tartışmaları gibi yeni iletişim uygulamaları ve yöntemleri açısindan dönüştürülmelidir.

Bilgi ve bilgilendirmenin anlamlı olması için, farklı zamanlarda farklı amaçlara, hedeflere uyacak şekilde dönüştürülmesi ve iletilmesi gerekir. $\mathrm{Bu}$, sürekliliği olan bir süreçtir. Her türlü teorik, uygulamalı, teknolojik ve sosyal yaklaşımlar kullanılarak bilgi, bilgilendirme ve araştırmanın dönüştürülmesine her zaman hazırlıklı olmak, kuşkusuz dönüştürücü müzenin en önemli görevi olacaktır. Bu aynı zamanda bir müzenin ele alamayacağı veya tartışamayacağı hiçbir konu veya temanın olmayacağı anlamına da gelir. Sürekli dönüşüm içinde olan bir müze, geçmişin bilgi ve gelenekleriyle, günümüzün çekişme, tartışmaları ve eğilimleriyle ve geleceğin fikirleriyle, düşünceleriyle ve firsatlarıyla şekillenen bir müze olacaktır.

\section{Müzelerdeki Dönüşümü Tanımlamak}

Modernizm ve postmodernizm arasında mey- dana gelen bazı değişikliklere ve yaklaşımların sürekli esnek ve dönüştürücü bir düşünme biçimine doğru nasıl değiştiğine baktığımızda, bu temel anlayışa dayalı birçok teriminin oluştuğunu görüyoruz. Bu tanımlar, müzecilik düşüncesindeki gelişmeleri göstermek için öznel olarak seçilmiştir.

Modern, postmodern ve dönüştürücü anlayışlardaki temel gelişmeler:

\begin{tabular}{lll}
\hline Modern & Postmodern & Dönüşü \\
\hline 1. Öğretici & Ziyaretçi Etkileşimi & Ziyaretçi Etkisi \\
\hline 2. Ulusal Odak & Küresel Odak & Dünya çapında (Web) \\
\hline 3. Kronoloji & Hikâye anlatma & Katılım \\
\hline 4. Nesnellik & Öznellik & Esneklik \\
\hline
\end{tabular}

1. Modern müzenin az çok öğretici tarzı, postmodern anlayışta ziyaretçi etkileşimine güçlü bir odaklanma haline dönüşmüştür. Bununla birlikte, artık ziyaretçiler için sadece etkileşim kurmanın yeterli olmadığını görüyoruz. Bir müze ziyaretinin öğrenme sürecine, sosyal ve bireysel deneyimine doğrudan bir etkiye sahip olmak amaçlanmaktadir.

2. Modern müze ulusal tarihe ve bir topluluğun kendi kökenine odaklanma eğilimindeyken, postmodern müze, küçük yerel müzeler de dâhil, amaçlarını küresel ortamlarda tanımladıkları, küresel bir müze haline gelmiştir. Dönüşümü küreselden daha geniş çaplı düşünebiliriz; dünya çapında ve özellikle her tür bilgiye dijital ortam aracılığıyla her zaman erişilebildiği için ziyaretçi her şeyi bilen durumundadır. İnsanlar örneğin Twitter, Facebook ve YouTube gibi sosyal web sitelerine katılırlar çünkü ilgi alanlarına ve tercihlerine göre hızla izleyebilmekte, katkıda bulunabilmekte ve bilgi edinebilmektedirler. Bu iletişim türleri, insanların nasıl yeni bilgiler edindiğini ve nasıl katılım sağlamak ve sosyalleşmek istediklerini şekillendirir. Dolayısı ile ziyaretçiler, her türlü bilginin bir sergi, etkinlik veya sosyal medya aracılığıyla erişilebilir olmasını beklemektedirler.

3. Birçok modern müze modeli, sergilerini belirli bir kronolojik sıralama, düzen veya sınıflandırmayla şeklinde sunmaktadır. Arkeolojik ve tarihi 
objeler genellikle yaş, boyut, malzeme veya kullanım yoluyla tanımlanmıştır. Postmodern müze, objelerin arkasındaki hikâyelere odaklanma eğilimindedir ve genellikle tarihi temalara odaklanır. Dönüşüm, hikâye anlatımının yanı sıra belli bir dereceye kadar katılımı da gerçekleştirmektedir. Burada önemli olan sadece ziyaretçilerin objelerle veya uygulamalarla etkileşime girmesi değil, artık ziyaretçilerin etkisi ve ziyareti kendilerinin şekillendirmesine izin verilmesi önem kazanmaktadır. Ziyaretçilere kendi hikâyelerini oluşturma, kendilerince ilginç buldukları bilgileri bulma ve kendi bilgi ve deneyimlerini paylaşarak ve ekleyerek etkinlik ve sergileri şekillendirme fırsatları verilmelidir. Ziyaretçiler, katılımcı olmak ve etkilerinin görünür ve yararlı olmasını talep etmektedirler.

4. Modern müze, koleksiyonları ağırlıklı olarak nesnel bir tarzda sunmuştur. $\mathrm{Bu}$, bir milletin tarihiyle ilgili sorulara sadece bir veya birkaç cevabın olduğu ve bu cevapların gerçek olarak kabul edildiği anlamına gelmektedir. Gerçek, müzelerde sunulduğu gibi algılanmaktaydı. Postmodern müze, müzelerin (ve bazen ziyaretçilerin) bir sergiye kendi etkilerini yaratma imkânı verdi. Dönüştürücü müze, ziyaretçiler kendi ilgi alanlarına göre bilgiyi araştıracakları için daha da fazla esnek olacaktır. Bu, ziyaretçilerin bazen uzman bilgisi, bazen sosyal katılım ve bazen dijital etkileşim vb. yollarla bilgiyi arayacağ 1 anlamına gelmektedir. Sunum, etkileşim ve yorumlama, talepler genişledikçe ve her türlü ziyaretçiye hitap etmesi gerektiğinden daha esnek ve sürekli dönüşüm içinde olacaktır.

\section{SONUÇ}

Postmodern müze kavram1, yeni bir müze konseptinin uygulanmasıyla ilgili çok önemli bir gelişme süreci içindedir. Son birkaç on yılda müzeler, sadece finansal zorluklar nedeniyle değil, aynı zamanda sorumluluk alanları da değiştiğinden yoğun bir baskı altında kalmaktadır. Mevcut müzeoloji tartışmaları ve teorideki gelişmeler sadece esneklik talep etmekle kalmamaktadır. Müzelerin iletişim uygulamalarında her türden ziyaretçiyi kapsadığı, herkesin gelişebileceği sosyal olarak kapsayıcı kurumlar oldukları ve aka- demik mükemmellik sunmaları gerektiği de belirtilmektedir. Tüm bu gereksinimleri karşılamak için müzeler koleksiyonlar, ziyaretçi etkileşimi, amaçlar, hedefler ve ilgileri konusunda farklı bir şekilde düşünmeye başlamalıdır. Gelecek nesiller, araştırmalar ve katılım için varlıklarını devam ettirmelidirler. Bu amaçlar ise sürekli esneklik, yaratıcı düşünme ve her şeyden önce dönüşüm gerektirmektedir.

Müzelerin değişmesi veya en azından değişime hazırlıklı olması gerektiği sıklıkla tartışılmaktadır. Ancak, bu dönüşüm üzerinde çok durulan bir kavram olmamıştır. Birincisi, müzeler zaten ziyaretçi ilgi ve isteklerine göre değişmektedir. İkinci olarak, değişim her müzenin amaçlarına, hedeflerine ve yaklaşımlarına bağlı bir şekilde bireysel olarak gerçekleşecektir. Müzelerin gelişmesi için her şeyin değişmesi gerekmediğini de unutmamak gerekir. Bununla birlikte, müzelerin engin bilgi ve araştırmalarını her türlü yorumlama, etkileşim, iletişim ve katılıma dönüştürebilmeleri gerekmektedir. Bu nedenle küratörün rolü daha geniş ve sosyal olarak çok daha kapsayıcı hale gelmektedir. Aynı zamanda kendi alanlarında uzman olarak küratörler, bilgilerini tüm ziyaretçi gruplarına, yeni teknolojik özelliklere, çevrimiçi iletişim ve araştırmalara uyacak şekilde kullanılabilir, ayrıca erişilebilir ve esnek hale getirmelidirler. Bu, gerçek değişimden çok dönüşümü gerektirir. Ne kadar çok müze, dönüştürücü yaklaşımları teorileri ve uygulamaları planlamaya başlarsa, gelecekteki zorluklar ve olasılıklar için o kadar iyi hazırlanmış olacaklardır.

\section{NOTLAR}

(1) Uluslararası Müzeler Konseyi (ICOM), Müze tanım1, http://archives.icom.museum/hist_def_eng. html, Erişim tarihi: 16 Ocak 2012.

(2) Dönüştürücü Müze terimi ilk olarak 2012'de konferans başlığı olarak kullanıldı.

DREAM (Danimarka Eğitim ve İleri Medya Materyalleri Araştırma Merkezi) tarafından düzenlenen bir konferans ile: DREAM - Danimarka Eğitim ve İleri Medya Materyalleri Araştırma Merkezi: Dönüştürücü Müze Konferansı: $h t t p: / /$ www.dreamconference.dkl, (Erişim tarihi: 19 Mart 2013). 
(3) Kelvingrove Sanat Galerisi ve Müzesi

http://www.glasgowlife.org.uk/museums/kelvingrove/ Pages/default.aspx, (Erişim tarihi: 8 Eylül 2012).

\section{TEŞEKKÜR}

Leicester Üniversitesi'ndeki Müzelerde Dönüşüm Doktora Konferansı organizatörlerine, bu makalenin dayandı $\breve{g}_{1}$ bir bildiriyi sunma fırsatı sundukları için içten teşekkürler.

\section{KAYNAKÇA}

Bell, W. (2009). Foundations of Future Studies. History, Purposes, Knowledge. Volume 1. Human Science for a New Era. New Brunswick. New Jersey: Transaction Publishers.

Black, G. (2012). Transforming Museums in the Twenty-first Century. Londra ve New York: Routledge.

Foucault, M. (1972). The Archaeology of Knowledge. Londra: Tavistock Publications Limited.
Heal, S. (2012). Editorial: It's not a Case Of The Public Or Collections', Museums Journal, 4.

Holt, J. (2013). The Curators, Museums Journal, 113 (3): 30-33.

Hooper-Greenhill, E. (2000). Museums and the Interpretation of Visual Culture. Londra ve New York: Routledge.

Houghton, N. (2004). Futures and Complex Thinking: Stepping Through The Doorstep of Dialectics. Monograph Series Australian Foresight Institute, Swinburne University, (6): 47-60.

Morgan, J. (2013). Examining the 'Flexible Museum': Exhibition Process, A Project Approach, and The Creative Element, Museum and Society, 11 (2): 158-171.

Naismith, L. (2004). Transformative Cycle. Monograph Series, Australian Foresight Institute, Swinburne University, (6): 21-45.

Sharp, R. (2012). Flexible Thinking, Museums Journal, 112 (10): 24-29.

Slaughter, R. A. (2004). The Transformative Cycle: a Tool for Illuminating Change. Monograph Series, Australian Foresight Institute, Swinburne University, (6): 5-19.

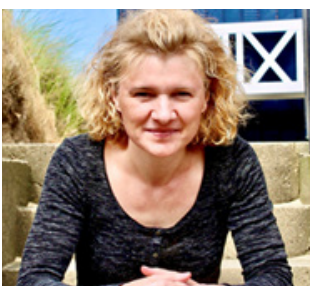

Jane K. NIELSON

Doktorasını 'Müze ve Miras'ın Yorumlanması' üzerine İskoçya, St. Andrewes Üniversitesi'nde tamamlamıştır. 'Müze Çalışmaları' üzerine yüksek lisansını İngiltere, Leicester Üniversitesi'nde ve Arkeoloji üzerine yüksek lisansını Danimarka, Aarhus Üniversitesi'nde tamamlamıştır. Yorumlama ve hikâye anlatımı üzerine uluslararası çeşitli projelerde görev almıştır.

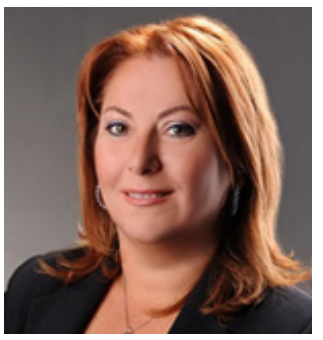

Fethiye ERBAY

İstanbul Üniversitesi İşletme Fakültesi'nde 'Çağdaş Müze İşletmesine Yönelik Uluslararası Bir Çalışma' üzerine doktorasını ve 'Sanatın Yönetimi' üzerine doktora çalışmasını Marmara Üniversitesi'nde tamamlamıştır. 'Müzelerin Personel Yönetimi, Organizasyon ve Eğitim' bașlıklı yüksek lisansını İstanbul Üniversitesi İşletme Fakültesi'nde tamamlamıştır. Leicester Üniversitesi'nde Müze Yönetimi Programı́na devam etmiştir. İstanbul Üniversitesi Sosyal Bilimler Fakültesi Müze Yönetimi Bilim Dalı Bölüm Başkanı'dır.

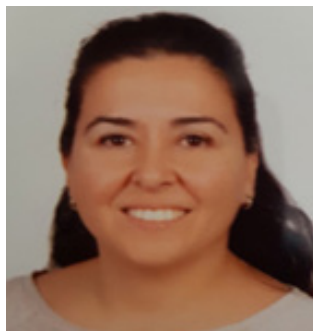

\section{Özgül ÇETIN}

Müzelerde Oyunlaştırma Uygulamaları' başıklı yüksek lisansını İstanbul Üniversitesi Sosyal Bilimler Fakültesi Müze Yönetimi Bilim Dalı’nda tamamlamıștır. Milli Saraylar İdaresi Başkanlığı Resim Müzesi'nde rehber olarak görev yapmaktadır. 